\title{
Prey composition and daily rations of myctophid fishes in the Southern Ocean
}

\author{
E. A. Pakhomov*, R. Perissinotto, C. D. McQuaid \\ Southern Ocean Group, Department of Zoology and Entomology, Rhodes University, PO Box 94, Grahamstown, \\ 6140, South Africa
}

\begin{abstract}
The feeding ecology of myctophids was studied using data collected during 5 South African scientific cruises to the Southern Ocean from 1985 to 1995. A total of 362 specimens, comprising 36 species, were analyzed for gut contents. Myctophid biomass levels, estimated from Bongo net tows, are among the lowest yet recorded for the Southern Ocean. Peak biomass levels were associated with the main frontal zones and with a permanent polynya region in the Lazarev Sea. Results show that all myctophid species are opportunistic mesozooplankton feeders exhibiting a high degree of overlap in their food spectrum and consuming primarily the most abundant species of copepods, euphausiids, hyperiids and pteropods. Daily rations were estimated using 3 different approaches and ranged from 0.2 to $4.4 \%$ of dry body weights. Generally, the daily food intake was equivalent to 0.5 (lower mean) to 2.9 (upper mean) of dry body weight for Antarctic and subantarctic species, and between 1.2 and $3.8 \%$ for temperate and subtropical species. Antarctic krill, Euphausıa superba, was usually poorly represented in the stomachs of all but 1 myctophid species. The results of this study therefore do not support the hypothesis that krill plays a major role in the feeding ecology and budget of myctophids.
\end{abstract}

KEY WORDS: Myctophid fishes · Antarctica - Feeding - Dally ration

\section{INTRODUCTION}

The Southern Ocean exhibits a distinct myctophid or lanternfish (family Myctophidae) fauna of $\sim 40$ endemic species (Bekker 1983, 1985). There are almost no truly epipelagic myctophids south of the Subtropical Convergence (STC) and most species are meso- and bathypelagic migrators (Gon \& Heemstra 1990). The total biomass of mesopelagic fish in the Southern Ocean (south of the STC) has been estimated from survey data and model calculations to range between 212 and 396 million $t$ (Lubimova et al. 1987). South of $40^{\circ} \mathrm{S}$ the biomass of myctophids alone ranges from 70 to 200 million t (Tseitlin 1982, Lubimova et al. 1987, Lancraft et al. 1989). This large myctophid stock has attracted some research attention in the past and recently the economic and general ecological importance of myctophids, as a link between meso- and macrozooplankton and top predators (e.g. fish, squid, birds and mam-

-E-mail: zoep@warthog.rv.ac.za mals), has stimulated great interest (Lubimova et al. 1987, Kozlov \& Tarverdieva 1989, Perissinotto \& McQuaid 1992, Sabourenkov 1992). Dense concentrations of myctophids are generally recorded in the Antarctic Polar Front Zone (APFZ), in the region between the Subantarctic Front and the Antarctic Polar Front (APF) (Chindonova 1987, Lubimova et al. 1987). However, the highest densities are consistently found within the major frontal systems, including the Marginal lce Zone (Chindonova 1987, Lancraft et al. 1989, 1991, Filin et al. 1991, Kozlov et al. 1991, Pakhomov et al. 1994).

A recent model of the Antarctic pelagic subsystem suggests that approximately $23 \%$ of the total primary production may be indirectly ingested by pelagic fish and squid (Huntley et al. 1991). Myctophids may, thus, represent a pathway accounting for a substantial export of organic carbon from the euphotic zone to the deep ocean through their diurnal vertical migrations and production of large, fast-sinking faeces. Therefore, any effort towards a correct estimation of energy transfer within the pelagic subsystem of the Southern Ocean must include analyses of the individual diet 
composition of these fishes and their rates of food consumption. Although, the diet of the most common and abundant myctophid species is well documented (Rowedder 1979, Naumov et al. 1981, Williams 1985, Hopkins \& Torres 1989, Kozlov \& Tarverdieva 1989, Oven et al. 1990, Lancraft et al. 1991, Sabourenkov 1991, Hopkins et al. 1993), to date there are only 2 estimates of daily rations available in the literature (Rowedder 1979, Gerasimova 1991).

The main aims of this study are to estimate daily rations of myctophid fishes in the Southern Ocean (including the STC region) and to provide further information on the feeding ecology of these important components of the mesopelagic subsystem.

\section{MATERIALS AND METHODS}

Myctophids were collected during 5 South African cruises to the Southern Ocean (Fig. 1, Table 1). Two cruises were undertaken aboard RV 'Africana', to the Prydz Bay region in March 1985 and to South Georgia in February 1994 (Fig. 1). During both cruises, samples were collected using the Polish Krill Trawl 1641 with a nominal mouth area of $\sim 30 \mathrm{~m}^{2}$ and a mesh size of $7 \mathrm{~mm}$. In the Prydz Bay region, trawls were towed obliquely between the surface and $\sim 80 \mathrm{~m}$ depth, while in the South Georgia shelf region tows were undertaken as close as possible to the bottom. During the northbound leg of the South Georgia cruise (March 1994), an additional tow was made in the mid-Atlantic region of the STC (Fig. 1).
The other 3 cruises were undertaken aboard the SA 'Agulhas', and formed part of the South African Antarctic Marine Ecosystem Study (SAAMES). The first, SAAMES II, took place during the period January to February 1993 along a transect between SANAE and Cape Town (Fig, 1). During the second cruise, SAAMES III (June to July 1993), the area of investigation was limited to the region south of Africa situated in the vicinity of the Subtropical Convergence (Fig. 1). The third survey, SAAMES IV (December 1994 to January 1995), was carried out in the Marginal Ice Zone (MIZ) of the Lazarev Sea (Fig. 1). During these surveys, fish were collected using a Bongo net with a mouth area of $0.5 \mathrm{~m}^{2}$ and a mesh size of 0.3 to $0.5 \mathrm{~mm}$ as well as with a Rectangular Midwater Trawl (RMT-8) with a nominal mouth area of $8 \mathrm{~m}^{2}$ and a mesh size of $4.5 \mathrm{~mm}$ (Baker et al. 1973). Both nets were fitted with an Universal Underwater Unit ( $\mathrm{U}^{3}$; Robertson et al. 1981). The volume filtered by the Bongo net was calculated using electronic flowmeter data while for the RMT- 8 this was determined by multiplying the effective mouth area of the trawl by the distance travelled (Roe et al. 1980). This was calculated from the ship's speed and the tow duration after the trawl was opened in the water. Towing speed varied between 1.5 and 4 knots and usually nets were towed obliquely between 0 and $300 \mathrm{~m}$. During the SAAMES IV survey only, some deep tows were made with the RMT- 8 trawl to a depth of $1000 \mathrm{~m}$.

Samples were preserved in 4 to $6 \%$ buffered formalin and examined in the laboratory. All myctophids isolated from the samples were identified to the species level and their standard body length (accuracy:

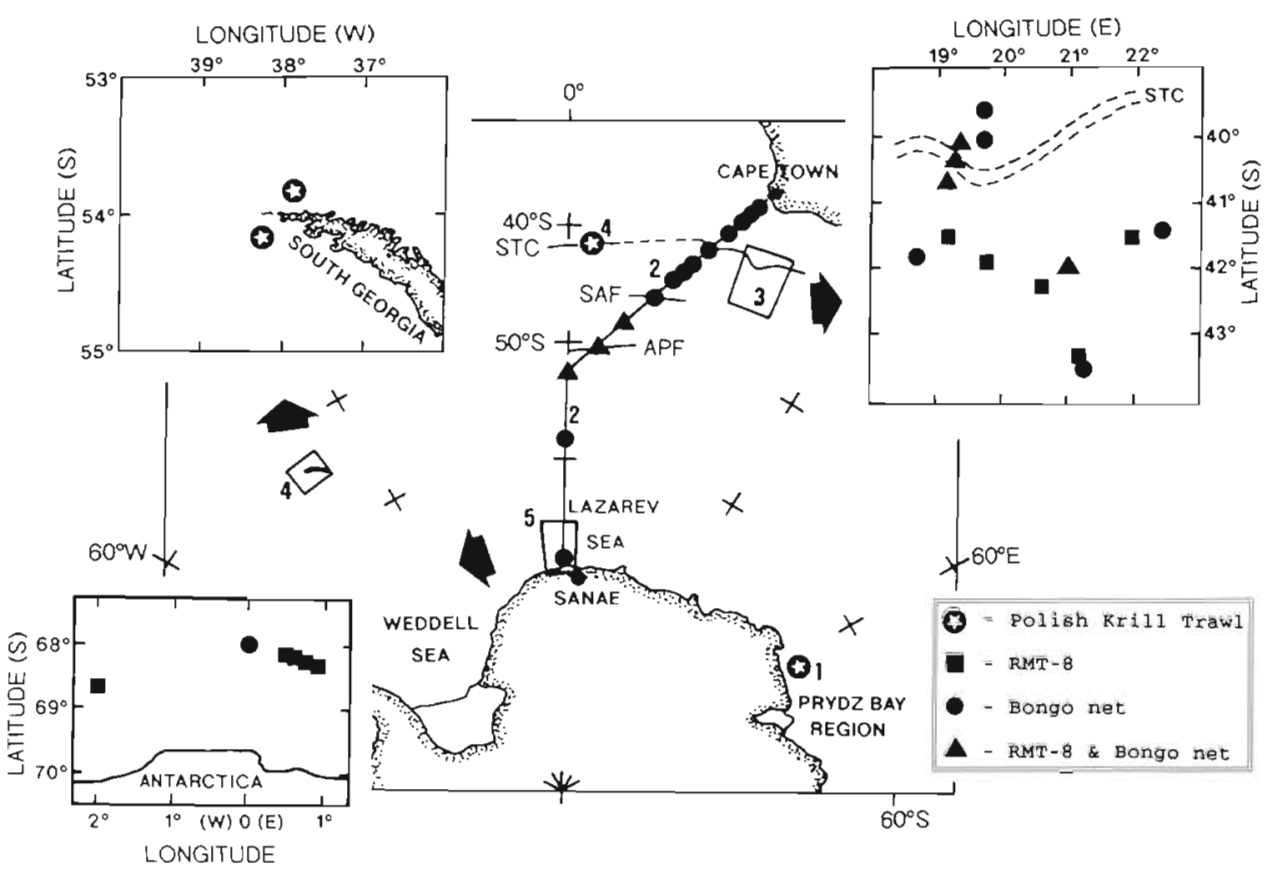

Fig. 1. Position of the stations where myctophids were collected in the Atlantic and Indian sectors of the Southern Ocean during 1: March 1985; 2: January to February 1993, SAAMES II $i$ 3: June to July 1993, SAAMES III; 4: February to March 1994 ; 5: December 1994 to January 1995, SAAMES IV. STC: Subtropical Convergence, SAF: Subantarctic Front; APF: Antarctic Polar Front 
Table 1. List of myctophid species examined for gut contents. APF: Antarctic Polar Front; STC: Subtropical Convergence; AD: Antarctic Divergence; AZ: Antarctic Zone; STZ: Subtropical Zone; SAZ: Subantarctic Zone

\begin{tabular}{|c|c|c|c|c|c|c|c|}
\hline \multirow{2}{*}{ Species } & \multirow{2}{*}{ Distribution } & \multicolumn{5}{|c|}{ Sampling period } & \multirow{2}{*}{ Tota } \\
\hline & & $\begin{array}{l}\text { Mar } \\
1985\end{array}$ & $\begin{array}{c}\text { Jan-Feb } \\
1993\end{array}$ & $\begin{array}{c}\text { Jun-Jul } \\
1993\end{array}$ & $\begin{array}{c}\text { Feb-Mar } \\
1994\end{array}$ & $\begin{array}{c}\text { Dec } 1994- \\
\text { Jan } 1995\end{array}$ & \\
\hline Electrona antarctica & $\mathrm{AZ}$ & 14 & 2 & - & - & 36 & 52 \\
\hline E. paucirastra & STC & - & - & - & 8 & - & 8 \\
\hline E. subaspera & SAZ & - & - & 1 & 1 & - & 2 \\
\hline E. carlsbergi & SAZ & - & 2 & - & - & - & 2 \\
\hline Metelectrona herwigi & STC & - & - & - & 12 & - & 12 \\
\hline Protomyctophum normani & STC & - & 1 & 22 & 15 & - & 38 \\
\hline P. bolini & $\mathrm{STC}-\mathrm{AD}$ & - & 5 & - & - & - & 5 \\
\hline P. horiodon & $36-51^{\circ} \mathrm{S}$ & - & 3 & - & 1 & - & 4 \\
\hline P. luciferum & $34-48^{\circ} \mathrm{S}$ & - & 1 & 1 & - & - & 2 \\
\hline P. andriashevi & STC-APF & - & 4 & - & - & - & 4 \\
\hline Diaphus taaningi & STZ & - & 1 & 16 & - & - & 17 \\
\hline D. hudsoni & SAZ & - & - & 3 & 15 & - & 18 \\
\hline D. efflugens & $19^{\circ} \mathrm{S}-\mathrm{STC}$ & - & - & 1 & - & - & 1 \\
\hline D. luetkeni & STZ & - & - & 2 & - & - & 2 \\
\hline D. meadi & STC & - & - & 2 & - & - & 2 \\
\hline Bentosema suborbitale & $50^{\circ} \mathrm{N}-50^{\circ} \mathrm{S}$ & - & 2 & 4 & - & - & 6 \\
\hline Gymnoscopelus nicholsi & STC-APF & 6 & - & - & 27 & - & 33 \\
\hline G. opisthopterus & $\mathrm{AZ}$ & 25 & - & - & - & 7 & 32 \\
\hline G. bolini & SAZ & - & 3 & 7 & - & - & 10 \\
\hline G. microlampas & STC-APF & - & 1 & - & - & - & 1 \\
\hline Ceratoscopelus warmingi & $42^{\circ} \mathrm{N}-45^{\circ} \mathrm{S}$ & - & 3 & 11 & 31 & - & 45 \\
\hline Symbolophorus boops & SAZ-STC & - & - & 2 & 24 & - & 26 \\
\hline S. evermanni & STZ & - & - & 1 & - & - & 1 \\
\hline S. barnardl & $30^{\circ} \mathrm{S}-\mathrm{STC}$ & - & 2 & - & - & - & 2 \\
\hline Hygophum hansen & STZ, STC & - & 2 & 2 & - & - & 4 \\
\hline H. higomii & STZ, STC & - & ${ }_{-}^{2}$ & $\begin{array}{l}5 \\
5\end{array}$ & - & - & 5 \\
\hline Lampanyctus alatus & STZ-STC & - & - & 3 & - & - & 3 \\
\hline L. dustralis & SAZ, STC & - & 2 & 2 & - & - & 4 \\
\hline L. pusillus & STZ & - & 1 & $i$ & - & - & 2 \\
\hline Krefftichthys andersoni & $\mathrm{STC}-\mathrm{AD}$ & - & 3 & - & - & - & 3 \\
\hline Lobianchia dolfeni & $50^{\circ} \mathrm{N}-40^{\circ} \mathrm{S}$ & - & - & 3 & - & - & 3 \\
\hline Lampadema ponifex & STZ & - & - & 2 & - & - & 2 \\
\hline Diogenichthys atlanticus & $50^{\circ} \mathrm{N}-48^{\circ} \mathrm{S}$ & - & - & 3 & - & - & 3 \\
\hline Scopelopsis multipunctatus & $25^{\circ} \mathrm{S}-\mathrm{STC}$ & - & - & 2 & - & - & 2 \\
\hline Notoscopelus resplendens & $47^{\circ} \mathrm{S}-\mathrm{STC}$ & - & 5 & - & - & - & 5 \\
\hline Bolinichthys supralateralis & STZ-STC & - & 1 & - & - & - & 1 \\
\hline Total & & 45 & 40 & 100 & 134 & 43 & 362 \\
\hline
\end{tabular}

$\sim 0.5 \mathrm{~mm}$ ) and wet weight (accuracy: $\sim 1 \mathrm{mg}$ ) measured. Dry weight was obtained by oven-drying specimens at $60^{\circ} \mathrm{C}$ for $48 \mathrm{~h}$. Prey items were isolated from myctophid gut contents, counted and where possible identified. In total 362 specimens, comprising 36 species of myctophids, were examined for gut contents (Table 1). Stomach contents were then dried at $60^{\circ} \mathrm{C}$ for $36 \mathrm{~h}$. Results from stomach content analyses were expressed as a percentage of each food item to the total number of food items counted. The degree of stomach fullness was estimated according to the procedure suggested by Sameoto (1989). The index of stomach fullness (ISF), expressed as a percentage of body weight, was calculated by dividing the dry weight of the stomach contents by the dry weight of the fish body.
To estimate daily rations of myctophids, 3 independent approaches were followed.

Approach 1. The mean specific daily ration $\left(C_{\mathrm{w}}\right)$ was calculated using Baikov's relation (Baikov 1935, Eggers 1977), $C_{\mathrm{w}}=I \times 24 / T$, where $I$ is the daily average ISF in $\%$ and $T$ is the gut passage time in hours. Samples collected at our $24 \mathrm{~h}$ stations indicated that myctophid stomachs contain fresh food throughout the night. This suggests that fish could feed for at least 8 to $10 \mathrm{~h} \mathrm{~d}^{-1}$. Taking this into account, Baikov's equation can be amended as follows: $C_{w}=I \times 10 / T$. Since the gut passage time for the species studied is unknown, data on gut passage time versus temperature from the literature were used. Given that both fish size and food type may significantly affect the gut evacuation rate 
(Fänge \& Grove 1979), only published data on gut passage time of fish with similar characteristics in terms of size range $(3$ to $10 \mathrm{~cm}$ ) and diet composition (zooplankton) were selected (Table 2). In some cases, both published and field data, collected at $24 \mathrm{~h}$ stations within the STC region (SAAMES III), were used to calculate gut evacuation rates $(k)$ and gut passage time $(1 / k)$. assuming an exponential model of food evacuation. A regression model between $1 / k$ and temperature was calculated from the values presented in Table 2 . This equation was very similar to the model derived from data obtained by Tyler (1970) from young cod maintained at temperatures of 2 to $19^{\circ} \mathrm{C}$. The $1 / \mathrm{k}$ values were also comparable to those published by Fänge \& Grove (1979).

Approach 2. Given the well documented diurnal vertical migrations and the predominantly nighttime feeding activity in myctophids (e.g Hopkins \& Baird 1977. Clarke 1978, Kinzer \& Schulz 1985, Gon \& Heemstra 1990), the assumption was made that the daily ration per fish is equal to the amount of fresh food found in a full stomach' (Sameoto 1988, 1989). For this purpose, values of ISF of full stomachs $(100 \%$ of stomach fullness, according to Sameoto 1989) for all myctophid species investigated were transformed using the arcsin operator and combined to calculate a regression equation between the standard fish body length (in mm) and ISF (in \% of body weight). Maximum daily ration derived in this way may be underestimated because fish may maintain a full stomach even while digesting or when food is transferred from the stomach to the hind gut during nighttime (Sameoto 1988). Therefore, 2 regressions were calculated (Fig. 2): in the first all data points were considered while in the sec-

Table 2. Available estimates of gut evacuation rate $(k)$ and gut passage time $(1 / k)$ versus temperature in a selected range of fish species. The relationship between $1 / k$ and water temperature $(T)$ from data presented in the table is a power function of the form: $1 / k=24.3 \times T^{-0.5}\left(\mathrm{R}^{2}=57.1 \%, \mathrm{p}<0.001\right)$

\begin{tabular}{|c|c|c|c|c|}
\hline Fish species & $T\left({ }^{\circ} \mathrm{C}\right)$ & $k\left(h^{-1}\right)$ & $1 / k(h)$ & Source \\
\hline Clupea harengus (larvae) & 7.0 & 0.133 & 7.5 & Blaxter (1963) \\
\hline Clupea harengus (larvae) & 9.0 & 0.161 & 6.2 & Blaxter $(1963)$ \\
\hline Clupea harengus (larvae) & 11.0 & 0.200 & 5.0 & Blaxter (1963) \\
\hline Clupea harengus (larvae) & 15.0 & 0.250 & 4.0 & Blaxter (1963) \\
\hline Lampanyctus mexicanus & 12.0 & 0.166 & 6.02 & Holton (1969) \\
\hline Pungitius pungitius & 5.0 & 0.050 & 20.0 & Cameron et al. (1973) \\
\hline Pungitius pungitius & 15.0 & 0.143 & 7.0 & Cameron et al. (1973) \\
\hline Perca flavescens & 22.0 & 0.250 & 4.0 & Nobel (1973) \\
\hline Diaphus taaningi & 13.0 & 0.238 & 4.20 & Baird et al. (1975) \\
\hline Brevoortia tyrranus & 16.0 & 0.200 & 5.0 & Kjeldson et al. (1975) \\
\hline Lagodon rhomboides & 16.5 & 0.180 & 5.55 & Kjeldson et al. (1975) \\
\hline Lagodon rhomboides & 16.0 & 0.194 & 5.15 & KJeldson et al. (1975) \\
\hline Leiostomus anthurus & 17.0 & 0.164 & 6.1 & Kjeldson et al. (1975) \\
\hline Hygophum proximum & 12.5 & 0.520 & 1.92 & Clarke (1978) \\
\hline Valenciennellus tripunctatus & 10.0 & 0.220 & 4.55 & Clarke (1978) \\
\hline Danaphos oculatus & 8.0 & 0.100 & 10.0 & Clarke (1978) \\
\hline Vincigueria nimbaria & 11.7 & 0.380 & 2.63 & Clarke (1978) \\
\hline Electrona antarctica ${ }^{\text {d }}$ & 3.0 & 0.118 & 8.5 & Rowedder (1979) \\
\hline Notothenia angustifrons & 1.0 & 0.027 & 37.0 & Targett (1981) \\
\hline Notothenia larseni & 1.0 & 0.049 & 20.4 & Targett (1981) \\
\hline Pleuronectes platessa ${ }^{\mathrm{a}}$ & 10.0 & 0.094 & 10.6 & Jobling (1986) \\
\hline Brama brama (juveniles) & 14.0 & 0.130 & 7.69 & Krasnopeyor (1990) \\
\hline Brama brama (juveniles) & 16.0 & 0.150 & 6.67 & Krasnopeyor (1990) \\
\hline Brama brama (juveniles) & 18.0 & 0.180 & 5.55 & Krasnopeyor (1990) \\
\hline Brama brama (juveniles) & 20.0 & 0.210 & 4.76 & Krasnopeyor (1990) \\
\hline Electrona carlsbergi ${ }^{\circ}$ & 3.5 & 0.125 & 8.0 & Gerasimova (1991) \\
\hline Clupea harengus (juveniles) & 17.4 & 0.352 & 2.84 & Arrhenius \& Hansson (1994) \\
\hline Clupea harengus (juveniles) & 16.5 & 0.242 & 4.13 & Arrhenius \& Hansson (1994) \\
\hline Clupea harengus (juveniles) & 15.0 & 0.272 & 3.67 & Arrhenius \& Hansson (1994) \\
\hline Clupea harengus (juveniles) & 13.2 & 0.223 & 4.48 & Arrhenius \& Hansson (1994) \\
\hline Clupea harengus (juveniles) & 8.7 & 0.197 & 5.08 & Arrhenius \& Hansson (1994) \\
\hline Diaphus taaningi & 12.0 & 0.169 & 5.92 & This study \\
\hline Protomyctophum normani ${ }^{d}$ & 12.0 & 0.158 & 6.33 & This study \\
\hline Pagothenia borchgrevinki ${ }^{\mathrm{b}}$ & -1.0 & 0.031 & 32.0 & Montgomery et al. (1989) \\
\hline
\end{tabular}




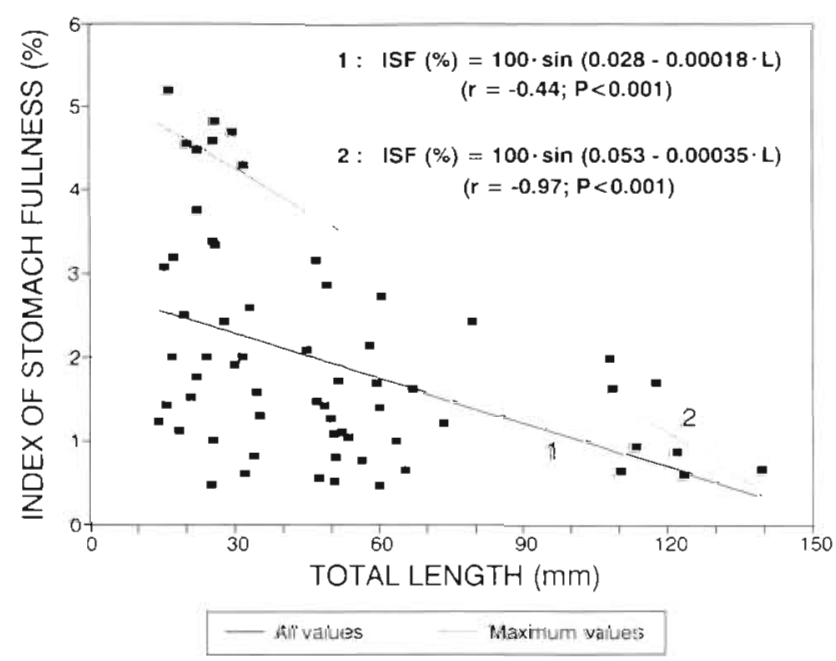

Fig. 2. Relationships between the index of stomach fullness (ISF, only stomachs with $100 \%$ fullness were considered Sameoto 1989) and fish standard length for myctophids species collected in the Southern Ocean. 1. relationship obtained for all values of $I S F_{i}$ 2: relationship calculated for the maximum ISF values for each $5 \mathrm{~mm}$ fish length size class

ond only the maximum values for each $5 \mathrm{~mm}$ fish size class were selected. Maximum values provide a more accurate estimate of the daily rations.

Approach 3. The last approach was based on estimates of fish metabolic energy requirements and net conversion efficiency, $K_{2}=P / P+R$ (where $P$ is production and $R$ is metabolic energy needs). Average values for $K_{2}$ in adult cold-water fish are $\sim 0.2$ (Vinberg 1956 , Brett \& Groves 1979). Thus, $P / R=0.25$. Since the consumption $C=P+R / U$ (where $U$ is the coefficient of assimilation), and assuming $U \sim 0.8$ (Hopkins \& Baird 1977), a value for $C$ of $\sim 1.56 \times R$ is obtained. Under natural conditions, $R$ is equal to $-2 \times R_{\mathrm{st}}$ (Vinberg 1956), where $R_{\mathrm{st}}$ is the basic metabolic needs. $R_{\mathrm{st}}$ values for Antarctic species were derived from Torres \& Somero (1988). For subantarctic and temperate species, average $R_{51}$ values obtained by Torres et al. (1979) using species held at $5^{\circ} \mathrm{C}$ and $10^{\circ} \mathrm{C}$, respectively, were used. Values of caloric content ( $\mathrm{kcal} \mathrm{g}^{-1}$ wet wt) were available in the literature for the following species: Electrona carlsbergi: 1.7 (Gerasimova 1991); E. antarctica and Gymnoscopelus spp.: 1.6; G. nicholsi: 2.8; G. opisthopterus and other species: 1.1 (Donnelly et al. 1990).

For example, according to Vinberg's equation the total daily energy requirements of Electrona antarctica estimated by doubling the basic metabolic requirements are:

$$
C_{\mathrm{w}}=1.56 \times 2 \times R_{\mathrm{s} 1} \times 24 \times 4.86 \times 100 / \mathrm{W} \times 1000
$$

where $R_{\mathrm{st}}=0.044 \times W^{0.946} \mathrm{ml} \mathrm{O}_{2} \mathrm{~h}^{-1}$ (Torres \& Somero $1988), 4.86 \mathrm{cal} \mathrm{ml}^{-1} \mathrm{O}_{2}$ is the oxycaloric coefficient and
$W$ is the average wet weight of the fish in grams. Since the caloric content of copepods and euphausiids (the staple food items of myctophids) is $\sim 0.7 \mathrm{kcal} \mathrm{g}^{-1}$ wet wt (Vinogradov \& Shushkina 1987), then the above equation can be reduced to:

$$
C_{w}=3.656 \times W^{-0.054} .
$$

To take into account the energy spent for reproduction, $C_{w}$ must be further increased by $\sim 19 \%$ (Tseitlin 1989)

\section{RESULTS}

\section{Myctophid biomass distribution}

Biomass levels, derived from Bongo net samples collected only during the nighttime tows and from the upper $300 \mathrm{~m}$ layer along the SANAE to Cape Town

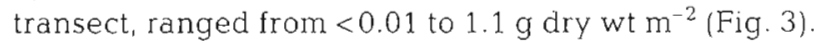
Average biomass throughout the transect was $0.138 \mathrm{~g}$ dry w $\mathrm{m}^{-2}$ (Table 3). Mesoscale enhancements in myctophid biomass generally co-occurred with high mesozooplankton densities (Fig. 3). The highest levels were recorded at a station situated at $60^{\circ} \mathrm{S}$, immediately north of the MIZ (Fig 3). The second major peak in biomass was observed in the northern vicinity of the APF, extending across the APFZ. Minor peaks were found in the polynya region off SANAE and in the southern vicinity of the A.PF. In addition, 2 small but consistent biomass enhancements were associated with the STC and the continental slope/shelf of South Africa (Fig. 3). Biomass levels available in the literature are also presented in Table 3 for comparison with the data obtained during this study.

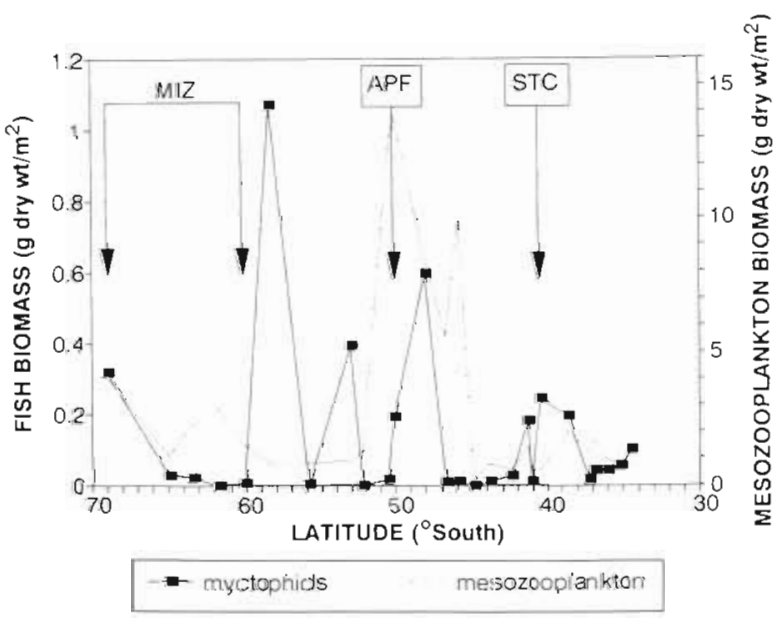

Fig. 3. Myctophid fish and mesozooplankton biomass along the transect from SANAE to Cape Town obtained from samples collected with 0 to $300 \mathrm{~m}$ oblique nighttime Bongo net tows during January to February 1993, SAAMES Il 
Table 3. Estimates of myctophid biomass in the Southern Ocean. APFZ: Antarctic Polar Front Zone (48 to $54^{\circ}$ S); APF: Antarctic Polar Front; STC: Subtropical Convergence; MIZ: Marginal Ice Zone

\begin{tabular}{|c|c|c|c|c|c|}
\hline Region & Method & \multicolumn{2}{|c|}{$\begin{array}{c}\text { Mean biomass } \\
\left.\text { (g wet wt } \mathrm{m}^{-2}\right)\left(\mathrm{g} \text { dry wt } \mathrm{m}^{-2}\right)\end{array}$} & Dominant species & Source \\
\hline Atlantic sector & Combined & 3.0 & 0.9 & Various speries & Gjosaeter \& \\
\hline Indian sector & Combined & $3.1-4.7$ & $0.93-1.41$ & Various speries & Kawaguchi (1980) \\
\hline Pacific sector & Combined & 4.5 & 1.35 & Various speries & \\
\hline Atlantic sector, $40-54^{\circ} \mathrm{S}$ & $\begin{array}{l}\text { Net (max.) } \\
(0-1000 \mathrm{~m})\end{array}$ & $5-15$ & $1.5-4.5$ & Various species & Chindonova (1987) \\
\hline Atlantic sector, APFZ & $\begin{array}{l}\text { Acoustic \& } \\
\text { net }\end{array}$ & $\begin{array}{c}5.3-9.9 \\
(40-45)^{a}\end{array}$ & $\begin{array}{c}1.6-3.0 \\
(12-13.5)^{a}\end{array}$ & Varlous species & Zemsky (1987) \\
\hline Atlantic sector, APFZ & Acoustic & $\begin{array}{c}3.82-6.48 \\
\operatorname{Max} .70-100\end{array}$ & $\begin{array}{l}1.15-6.48 \\
\text { Max. } 21-30\end{array}$ & Electrona carlsbergi & Filin et al. (1991) \\
\hline Atlantic sector, APFZ & Acoustic & $1.6-11.72$ & $0.48-3.52$ & Electrona carlsbergi & Kozlov et al. (1991) \\
\hline Allantic sector, MIZ & $\begin{array}{l}\text { Net } \\
(0-1000 \mathrm{~m})\end{array}$ & - & $0.36-0.73$ & Various species & Lancraft et al. (1991) \\
\hline $\begin{array}{r}\text { Atlantic sector, APF } \\
\text { STC }\end{array}$ & $\begin{array}{l}\text { Net }(0-300 \mathrm{~m}) \\
\text { Net }(0-300 \mathrm{~m})\end{array}$ & $\begin{array}{l}- \\
-\end{array}$ & $\begin{array}{l}\text { Max. } 0.117 \\
\text { Max. } 0.302\end{array}$ & $\begin{array}{l}\text { Various species } \\
\text { Various species }\end{array}$ & Pakhomov et al. (1994) \\
\hline Atlantic sector & $\begin{array}{l}\text { Bongo net } \\
(0-300 \mathrm{~m})\end{array}$ & - & $\begin{array}{c}0.138 \\
\operatorname{Max} .1 .07\end{array}$ & $\begin{array}{l}\text { Various species } \\
\text { Electrona antarctica }\end{array}$ & $\begin{array}{l}\text { This study } \\
\text { This study }\end{array}$ \\
\hline Lazarev Sea, MIZ & $\begin{array}{l}\text { Net }(0-1000 \mathrm{~m}) \\
\text { Net }(0-1000 \mathrm{~m})\end{array}$ & $\begin{array}{l}- \\
-\end{array}$ & $\begin{array}{c}0.087 \\
\text { Max. } 0.806\end{array}$ & $\begin{array}{l}\text { Electrona antarctica } \\
\text { Electrona antarctica }\end{array}$ & $\begin{array}{l}\text { Pakhomov et al. } \\
\text { (unpubl.) }\end{array}$ \\
\hline "In sw & & & & & \\
\hline
\end{tabular}

\section{Water content and gravimetric analysis}

Water content, expressed as a percentage of wet weight, ranged from $60 \%$ in Gymnoscopelus nicholsi to $80.9 \%$ in G. microlampas (Table 4). Generally, water content showed an inverse correlation with fish size. The values of water content obtained in this study are within the range reported for temperate myctophids (e.g. Neighbors \& Nafpaktitis 1982, Baily \& Robison 1986) and also almost identical to the levels obtained by Donnelly et al. (1990) for several Antarctic species

Values for the coefficients $a$ and $b$ of the power function, obtained from the regression of standard length versus dry body weight, were generally similar in all species investigated and ranged from 0.0001 to 0.006 and from 2.7 to 3.7 , respectively (Table 4 )

\section{Stomach content composition}

The number of items per stomach examined generally ranged from 1 to 20 (Table 5a, b). Stomachs with more than 30 food items were very rare and contained a monospecific food type. The maximum number of food items in 1 stomach (185) was recorded for Krefftichthys andersoni (Table 5b). Average values of ISF ranged from 0.16 to $1.97 \%$ of dry body weight. Three species, i.e. Bentosema suborbitale, Lampadema ponifex and $K$. andersoni, had average ISFs as high as 2.4 to $4.5 \%$ of dry body weight (Table $5 \mathrm{a}$, b).

Copepods were the most important component in the diet of almost all myctophid species examined. In general, they accounted for $>50 \%$ by number of all prey items identified (Table $5 \mathrm{a}$, b). Medium-sized ( $\leq 5 \mathrm{~mm}$ ) bioluminescent species of the genera Metridia and Pleuromamma (exhibiting a large pigment spot on the cephalothorax) as well as large (5 to $8 \mathrm{~mm}$ ) species of the genera Calanus, Rhincalanus and Euchaeta were the dominant copepods consumed. Small ( $\leq 12 \mathrm{~mm}$ ) euphausiids, mainly Euphausia spp. and Thysanoessa spp., hyperiids, mostiy Themisto gaudichaudi and Primno macropa, and the pteropod, $L_{i-}$ macina spp., formed the next most abundant components of the myctophids diet (Table $5 \mathrm{a}, \mathrm{b}$ ). Antarctic krill Euphausia superba, with a total length of 33 to $43 \mathrm{~mm}$, was an important food item only in the adults of Gymnoscopelus opisthopterus. Most krill individuals found in fish stomachs were, however, undigested. Euphausiids were in general more important in the diet of fish with a standard length $>40 \mathrm{~mm}$, e.g Electrona paucirastra, Metelectrona hervigi, Gymnoscopelus nicholsi and G. opisthopterus (Tables 4 \& 5a).

\section{Daily rations}

Although estimates of daily rations for the most abundant myctophid species vary considerably $(0.23$ to $4.4 \%$ of dry body $w \mathrm{t}$ ), the values derived from the 3 different approaches used in this study are in reasonable agreement with each other and with those reported in the literature (Table 6). Consistently lower daily rations were obtained only when using the first approach, probably due to the limited number of fish examined. 
Table 4. Relationships between standard length, body dry weight and water content of the myctophid species analysed. Parameter values were fitted to the power function: $y=a \times x^{b}$, where $y$ is the body dry weight (mg) and $x$ is the standard length (mm)

\begin{tabular}{|c|c|c|c|c|c|c|c|c|}
\hline \multirow[t]{2}{*}{ Species } & \multirow[t]{2}{*}{$\mathrm{n}$} & \multirow{2}{*}{$\begin{array}{l}\text { Size range } \\
(\mathrm{mm})\end{array}$} & \multicolumn{3}{|c|}{ DW as $\%$ of WW } & \multirow[t]{2}{*}{ a } & \multirow[t]{2}{*}{$b$} & \multirow[t]{2}{*}{$r$} \\
\hline & & & Range & Mean & $\mathrm{SD}$ & & & \\
\hline Electrona antarctica & 52 & $25-85$ & $12.7-32.6$ & 25.3 & 5.47 & 0.0002 & 3.706 & 0.995 \\
\hline E. paucurastra & 8 & $48.5-65.8$ & $24.8-27.7$ & 26.0 & 0.95 & 0.0008 & 3.312 & 0.988 \\
\hline E. subaspera & 2 & $21.6-47$ & $19.1-22.3$ & 20.2 & 2.95 & - & - & - \\
\hline E. carisbergi & 2 & $13.2-17.6$ & $18.8-19.7$ & 19.2 & 0.67 & - & - & - \\
\hline Melelectrona herwigı & 12 & $46.3-57$ & $31-38.7$ & 34.6 & 2.35 & 0.0011 & 3.363 & 0.916 \\
\hline Protomyctophum normani & 58 & $17.5-55.5$ & $16.9-34.7$ & 25.9 & 4.33 & 0.0032 & 2.990 & 0.963 \\
\hline P. bolini & 5 & $53-57$ & $29.5-34.4$ & 31.0 & 1.78 & - & - & - \\
\hline P. horiodon & 4 & $25.4-75.5$ & $20.7-28.5$ & 25.3 & 3.02 & 0.0006 & 3.332 & 0.998 \\
\hline P. Iuciferum & 2 & $24-35$ & $21.8-26.3$ & 24.1 & 2.27 & - & - & - \\
\hline P. andriashevi & 4 & $23.7-51.6$ & $25.6-32.0$ & 27.8 & 2.61 & 0.0009 & 3.300 & 0.997 \\
\hline Diaphus taannngi & 17 & $12.4-59.5$ & $20-25.7$ & 22.8 & 1.56 & 0.0006 & 3.337 & 0.995 \\
\hline D. hudsoni & 18 & $15-47.3$ & $22.8-34.7$ & 29.3 & 3.52 & 0.0012 & 3.236 & 0.903 \\
\hline D. efflugens & 1 & 72.8 & - & 20.7 & - & - & - & - \\
\hline D. luetkeni & 2 & $31.6-32.9$ & $23.5-24.4$ & 24.0 & 0.65 & - & - & - \\
\hline D. meadi & 2 & $17-36$ & $22.4-23.5$ & 22.9 & 0.79 & - & - & - \\
\hline Bentosema suborbitale & 6 & $11-29$ & $20.4-27.6$ & 23.4 & 2.60 & 0.0030 & 2.920 & 0.994 \\
\hline Gymnoscopelus nicholsi & 33 & $69.1-1.39$ & $31.4-46.2$ & 40.0 & 3.45 & 0.0009 & 3.296 & 0.952 \\
\hline G. opisthopterus & 32 & $64-153.5$ & $14.7-31.6$ & 20.2 & 5.59 & 0.00003 & 3.873 & 0.980 \\
\hline G. bolini & 10 & $24.3-98.1$ & $20.6-30.4$ & 24.4 & 3.42 & 0.0004 & 3.377 & 0.996 \\
\hline G. microlampas & 1 & 32.6 & - & 19.1 & - & - & - & - \\
\hline Ceratoscopelus warmingi & 60 & $16.5-74.6$ & $16.5-27.8$ & 21.7 & 2.58 & 0.0004 & 3.361 & 0.995 \\
\hline Symbolophorus boops & 26 & $25-96.1$ & $21.4-27.5$ & 24.6 & 1.67 & 0.0002 & 3.517 & 0.997 \\
\hline S. evermanni & 1 & 22.1 & - & 22.2 & - & - & - & - \\
\hline S. barnardi & 2 & $2.3-24.7$ & $20-23$ & 21.5 & 1.51 & - & - & - \\
\hline Hygophum hanseni & 4 & $20.5-39.4$ & $22.2-25.0$ & 23.5 & 1.20 & 0.0022 & 2.993 & 0.966 \\
\hline H. higomii & 5 & $14.5-16.3$ & $17.9-20.9$ & 20.0 & 1.08 & - & - & - \\
\hline Lampanyctus alatus & 3 & $19.6-30.5$ & $21-24.6$ & 22.9 & 1.46 & 0.0009 & 3.070 & 0.999 \\
\hline L. australis & 4 & $25-37$ & $23.5-25.9$ & 24.4 & 0.98 & 0.0001 & 3.871 & 0.952 \\
\hline L. pusillus & 2 & $21.4-31.4$ & $20.5-26.7$ & 23.6 & 4.38 & - & - & - \\
\hline Krefftichthys andersoni & 3 & $14-52.1$ & $25.6-38.1$ & 33.9 & 5.85 & 0.0002 & 3.854 & 0.999 \\
\hline Lobianchia dolfeni & 3 & $34-38$ & $23.5-25.7$ & 24.7 & 0.92 & - & - & - \\
\hline Lampadema ponifex & 2 & $19.5-20$ & $20.7-20.9$ & 20.8 & 0.14 & - & - & - \\
\hline Diogenichthys atlanticus & 3 & $14-18.1$ & $19.9-21.0$ & 20.6 & 0.59 & - & - & - \\
\hline Scopelopsis multipunctatus & 2 & $16.7-17.2$ & $21.3-22.3$ & 21.8 & 0.55 & - & - & - \\
\hline Notoscopelus resplendens & 5 & $42.4-56.4$ & $22.4-24.9$ & 23.3 & 0.87 & 0.0057 & 2.728 & 0.958 \\
\hline Bolinichthys supralateralis & 1 & 17.1 & - & 19.5 & - & - & - & - \\
\hline
\end{tabular}

Generally, the daily consumption of Antarctic and high-subantarctic species ranged from 0.5 (lower mean) to $2.92 \%$ (upper mean) of dry body weight (Table 6). Daily rations for the temperate and subtropical species ranged between 1.34 and $3.85 \%$.

\section{DISCUSSION}

\section{Feeding ecology}

The results of this study indicate that Southern Ocean myctophids occupy an important trophic status as zooplankton consumers. Mesozooplanktonic organisms, such as copepods, euphausiids, hyperiids and pteropods, constitute the bulk of myctophid diets. As in most other regions of the world ocean, these fish constitute the tertiary level of the pelagic trophic system and are consumers of the second order (e.g. Hopkins \& Baird 1977, Clarke 1978, 1980, Gordon et al. 1985, Duka 1986, Kawamura \& Fujii 1988).

While studying the feeding ecology of a synoptic collection of 14 tropical myctophid species, Clarke (1980) found a high degree of feeding specialisation between species. In contrast, myctophids from temperate and high latitude regions appear to exhibit a high degree of overlap in their food spectrum (e.g. Tyler \& Pearcy 1975, Scotto di Carlo et al. 1982, Young \& Blaber 1986). In this study, we found no substantial differences in the prey items of myctophid species collected within the same region (Table $5 \mathrm{a}, \mathrm{b}$ ). This may reflect low interspecies food competition because of high regional food availability. This hypothesis is supported by the observation that at all stations myctophids fed on the most abundant species of mesozooplankton (e.g. Voronina 1984, Barange et al. in press, Pakhomov \& McQuaid in 
Table 5a. Diet composition of 20 myctophid species collected in the Southern Ocean during the period 1985-1995. EA. Electrona antarctica; EP: E. paucirastra; ES: E. subaspera; EC: E. carlsbergi; MH: Metelectrona herwigi; PN: Protomyctophum normani; PB: P. bolini, PH: P. horiodon; PL: P. Iuciferum; PA: P. andriashevi; DT: Diaphus taaningi; DH: D. hudsoni; DE: D. efflugens; DL: D. luetkeni; DM: D. meadi; BS: Bentosema suborbitale; GN: Gymnoscopelus nicholst; GO: G. opisthopterus; GB: G. bolini; GM: G. microlampas

\begin{tabular}{|c|c|c|c|c|c|c|c|c|c|c|c|c|c|c|c|c|c|c|c|c|}
\hline Stomach contents & EA & EP & ES & $\mathrm{EC}$ & $\mathrm{MH}$ & $\mathrm{PN}$ & PB & $\mathrm{PH}$ & PL & $\mathrm{PA}$ & DT & $\mathrm{DH}$ & $\mathrm{DE}$ & DL & $\mathrm{DM}$ & BS & $\mathrm{GN}$ & GO & $G B$ & GM \\
\hline \multicolumn{21}{|l|}{ Copepoda } \\
\hline Rhincalanus gigas & 1.0 & - & - & - & - & - & - & - & - & 12.5 & - & - & - & - & - & - & 10.9 & 2.8 & 2.3 & - \\
\hline Rhincalanus spp. & - & - & - & - & - & 0.9 & - & - & - & - & - & - & - & - & - & - & - & - & - & - \\
\hline Calanus propinquus & 20.5 & - & - & - & - & - & - & - & - & - & - & - & - & - & - & - & - & - & - & - \\
\hline Calanus simillimus & - & - & - & - & - & - & 6.7 & - & - & - & - & - & - & - & - & - & 18.1 & - & 6.8 & - \\
\hline Calanus spp. & - & - & 4.2 & - & - & - & - & - & 11.1 & - & 0.9 & - & - & - & - & 4.5 & 3.6 & - & 2.3 & - \\
\hline Calanoides acutus & 5.0 & - & - & - & - & - & - & - & - & - & - & - & - & - & - & - & 4.0 & - & - & - \\
\hline Clausocalanus spp. & 3.6 & - & - & - & - & - & - & - & - & 6.3 & - & - & - & - & - & - & 1.2 & - & - & - \\
\hline Ctenocalanus spp. & 3.6 & - & - & - & - & - & & - & 22.2 & 25.0 & - & - & - & - & - & - & - & - & - & - \\
\hline Scaphocalanus spp. & - & - & - & - & - & - & - & - & 11.1 & - & - & - & - & - & - & - & - & - & - & - \\
\hline Metridia gerlachei & 25.2 & - & - & - & - & - & 20.0 & - & - & - & & - & - & - & - & - & - & - & - & - \\
\hline Metridia lucens & - & 45.0 & 16.7 & - & - & - & - & - & - & - & 1.7 & - & - & - & - & - & - & - & 6.8 & - \\
\hline Metridja spp. & 1.8 & - & - & - & 8.8 & 2.3 & - & - & - & - & 9.4 & 1.6 & - & - & 11.1 & - & 10.2 & - & - & 20.0 \\
\hline $\begin{array}{l}\text { Pleuromamma } \\
\text { abdominalis }\end{array}$ & - & - & - & - & - & 0.9 & - & - & - & - & 1.7 & - & - & - & - & - & - & - & 31.8 & - \\
\hline Pleuromamma spp. & - & 2.5 & 29.2 & - & 11.7 & 70.6 & - & 11.1 & 33.3 & 12.5 & 56.4 & 40.9 & 50.0 & 16.7 & 33.3 & 36.4 & 0.2 & - & 4.6 & 20.0 \\
\hline Paraeuchaeta antarctica & 1.8 & - & - & - & - & - & 26.7 & - & - & - & - & - & - & - & - & - & 0.4 & 13.9 & - & - \\
\hline Euchaeta spp. & 4.7 & - & - & - & 1.5 & - & 33.3 & 11.1 & - & 6.3 & 0.9 & - & - & - & - & - & 5.4 & - & 2.3 & - \\
\hline Scolecitricella spp. & - & - & - & - & - & - & - & - & - & - & - & - & - & - & - & - & 0.2 & - & - & - \\
\hline Candacia spp. & - & - & - & - & - & - & - & 11.1 & - & - & - & - & & - & - & - & 0.6 & - & 4.5 & - \\
\hline Catlanoida & 8.2 & - & -3 & 33.3 & 5.9 & 14.2 & - & 33.3 & - & 25.0 & 9.4 & 6.6 & - & 66.7 & 33.3 & 13.6 & 10.8 & - & 11.4 & - \\
\hline Oithona spp. & - & - & -3 & 33.3 & - & - & - & - & - & - & - & - & - & - & - & - & - & - & - & - \\
\hline Oncaea spp. & - & - & 4.2 & - & - & 0.5 & - & - & - & - & 5.1 & 6.2 & - & - & 22.2 & 22.7 & - & - & - & 40.0 \\
\hline \multicolumn{21}{|l|}{ Ostracoda } \\
\hline Conchoecinae & 0.9 & - & - & - & - & - & - & - & 22.2 & 6.2 & 60 & 9.6 & - & - & - & 4.6 & 1.2 & - & 11.4 & - \\
\hline \multicolumn{21}{|l|}{ Euphausiacea } \\
\hline Euphausia superba & - & - & - & - & - & - & - & - & - & - & - & - & - & - & - & - & 2.5 & 16.7 & - & - \\
\hline Euphausia frigida & - & - & - & - & - & - & 6.7 & - & - & - & - & - & - & - & - & - & 4.8 & - & - & - \\
\hline Euphausia triacantha & - & - & - & - & - & - & - & 11.1 & - & - & - & - & - & - & - & - & 0.6 & - & - & - \\
\hline Euphausia spinifera & - & - & - & - & 1.5 & - & - & - & - & - & - & - & - & - & - & - & - & - & - & - \\
\hline Euphausia similis & - & 2.5 & - & -2 & 26.4 & - & - & - & - & - & - & - & - & - & - & - & - & - & - & - \\
\hline Euphausia (furcilia) & 1.4 & - & - & - & - & 0.9 & - & - & - & - & 0.8 & - & - & - & - & 182 & 1.4 & - & 2.3 & - \\
\hline Thysanoessa macrura & 3.6 & - & - & - & - & - & - & - & - & - & - & - & - & - & - & - & 0.8 & 16.7 & - & - \\
\hline Thysanoessa vicina & - & & - & - & - & - & - & - & - & - & - & - & - & - & - & - & 16.1 & - & - & - \\
\hline Thysanoessa gregaria & - & 5.0 & - & - & - & - & - & - & - & - & - & - & - & - & - & - & - & - & - & - \\
\hline Thysanoessa spp. & 0.5 & 10.0 & 4.2 & - & 5.9 & 3.2 & - & - & - & - & - & 1.6 & - & - & - & - & 0.2 & - & - & - \\
\hline $\begin{array}{c}\text { Nematoscelis } \\
\text { megalops }\end{array}$ & - & - & - & - & 1.5 & - & - & - & - & - & - & - & - & - & - & - & - & - & - & - \\
\hline Euphausiacea & 0.9 & 10.0 & - & - & 7.3 & 2.3 & - & - & - & - & 0.8 & 3.3 & - & - & - & - & 0.8 & 11.1 & 9.1 & - \\
\hline \multicolumn{21}{|l|}{ Mysidacea } \\
\hline $\begin{array}{c}\text { Antarctomysis } \\
\text { maxima }\end{array}$ & - & - & - & - & - & - & - & - & - & - & - & - & - & - & - & - & 0.4 & - & - & - \\
\hline \multicolumn{21}{|l|}{ Amphipoda } \\
\hline $\begin{array}{l}\text { Themisto } \\
\text { gaudichaudi }\end{array}$ & - & - & - & - & 1.5 & - & - & 22.2 & - & - & - & - & - & - & - & - & 1.8 & - & - & - \\
\hline Primno macropa & 0.9 & - & - & - & - & - & 13.3 & - & - & 6.2 & - & - & - & - & - & - & - & - & - & - \\
\hline Vibilia antarctica & 1.4 & - & - & - & - & - & - & - & - & - & - & - & - & - & - & - & 0.2 & - & - & - \\
\hline Hyperiella dilatata & 0.5 & - & - & - & - & - & - & - & - & - & - & - & - & - & - & - & - & - & - & - \\
\hline Phronima sedentaria & - & - & - & - & 1.5 & - & - & - & - & - & - & - & - & - & - & - & - & - & - & - \\
\hline Scina spp. & 0.9 & - & - & - & - & - & - & - & - & - & - & - & - & - & & - & - & - & - & - \\
\hline Hyperiidea & 0.9 & - & - & - & - & - & - & - & - & - & - & 3.3 & - & - & - & - & - & 2.8 & - & - \\
\hline \multicolumn{21}{|l|}{ Polychaeta } \\
\hline $\begin{array}{c}\text { Rhinchonerella } \\
\text { bongraini }\end{array}$ & 0.9 & - & - & - & - & - & - & - & - & - & - & - & - & - & - & - & - & - & - & - \\
\hline Polychaeta & 0.9 & - & - & - & - & - & - & - & - & - & - & - & - & - & - & - & 0.4 & - & 4.5 & - \\
\hline
\end{tabular}


Table 5a (continued; Table 5b overleaf)

\begin{tabular}{|c|c|c|c|c|c|c|c|c|c|c|c|c|c|c|c|c|c|c|c|c|}
\hline Stomach contents & EA & $\mathrm{EP}$ & ES & $\mathrm{EC}$ & $\mathrm{MH}$ & PN & $\mathrm{PB}$ & $\mathrm{PH}$ & PL & $\mathrm{PA}$ & DT & $\mathrm{DH}$ & DE & DL & DM & BS & GN & GO & $G B$ & GM \\
\hline \multicolumn{21}{|l|}{ Mollusca } \\
\hline Limacina spp. & 1.4 & 20.0 & 41.7 & - & 25.0 & 0.5 & - & - & - & - & 2.6 & 1.6 & - & - & - & - & 0.2 & - & - & - \\
\hline $\begin{array}{l}\text { Allurotheutis } \\
\text { antarcticus }\end{array}$ & - & - & - & - & - & - & - & - & - & - & - & - & - & - & - & - & - & 5.5 & - & - \\
\hline \multicolumn{21}{|l|}{ Chaetognatha } \\
\hline Eukrohnia hamata & 3.6 & - & - & - & - & - & - & - & - & - & - & 1.6 & - & - & - & - & 1.6 & 2.8 & - & - \\
\hline Sagitta spp. & 1.8 & - & - & - & - & - & - & - & - & - & - & - & - & - & - & - & 1.0 & - & - & - \\
\hline Chaetogntha & 2.7 & - & - & 33.3 & - & - & - & - & - & - & 1.7 & 1.6 & - & 16.6 & - & - & - & 2.8 & -2 & 20.0 \\
\hline \multicolumn{21}{|l|}{ Tunicata } \\
\hline Oikopleura spp. & - & 5.0 & - & - & - & - & - & - & - & - & - & 6.2 & - & - & - & - & - & - & - & - \\
\hline Salpa spp. & - & - & - & - & - & - & - & - & - & - & 0.8 & - & - & - & - & - & - & - & - & - \\
\hline Salpa thompsoni & 0.5 & - & - & - & - & - & - & - & - & - & - & - & - & - & - & - & - & 11.1 & - & - \\
\hline Salpidae & - & - & - & - & - & - & - & - & - & - & 0.9 & 6.2 & - & - & - & - & - & - & - & - \\
\hline \multicolumn{21}{|l|}{ Osteichthyes } \\
\hline Myctophidae & - & - & - & - & - & - & - & - & - & - & - & - & 50.0 & - & - & - & - & - & - & - \\
\hline Fish scales & 0.9 & - & - & - & 1.5 & 3.7 & - & - & - & - & 0.9 & 3.3 & - & - & - & - & - & 13.8 & - & - \\
\hline Total food items & 219 & 40 & 24 & 3 & 68 & 218 & 15 & 9 & 9 & 16 & 117 & 61 & 2 & 6 & 18 & 22 & 498 & 36 & 44 & 5 \\
\hline $\begin{array}{l}\text { No. of items } \\
\text { per stomach }\end{array}$ & $1-21$ & $1-21$ & 12 & $1-2$ & $1-21$ & $1-39$ & $2-7$ & $2-4$ & $3-6$ & $3-7$ & $1-47$ & $1-7$ & 2 & $2-4$ & 9 & $2-5$ & $1-38$ & $1-6$ & $1-10$ & 5 \\
\hline $\begin{array}{l}\text { Average ISF } \\
\text { values }(\%)\end{array}$ & 0.73 & 0.49 & 1.24 & 0.67 & 0.96 & 1.27 & 0.53 & 1.46 & 0.35 & 1.25 & 0.57 & 0.52 & 0.28 & 0.26 & 1.94 & 2.78 & 0.49 & 0.38 & 0.16 & 1.02 \\
\hline
\end{tabular}

press). This is further confirmed by the spatial covariance between high myctophid densities and mesozooplankton biomass enhancement (Fig. 3). Antarctic, subantarctic and temperate/subtropical species of myctophids can, therefore, be classified as opportunistic mesozooplankton predators, with dietary preferences being solely a function of prey availability (Hopkins \& Baird 1977)

Our data do not allow serious consideration of dietary changes during the life span of myctophids. The results do, however, show that euphausiids and hyperiids are more important in the diet of adult fish compared to the earlier stages. The available literature indicates that small euphausiids (such as Thysanoessa spp.) and hyperiids (mainly Themisto gaudichaudi) are the most consistent components in the food of adult Antarctic myctophids (Naumov et al. 1981, Kozlov \& Tarverdieva 1989, Oven et al. 1990). This agrees with the conceptual model of a relationship between fish size and prey size, biomass and diversity as suggested for tropical myctophid species by Scotto di Carlo et al. (1982). Some studies have shown that adults of the most abundant Antarctic myctophids feed on krill, rather than copepods (Rowedder 1979, Naumov et al. 1981, Zasel'sljy et al. 1985, Kozlov \& Tarverdieva 1989, Oven et al. 1990). This has important implications since it has been suggested that mesopelagic fish, and not seabirds and mammals, may be the dominant predators of krill in the Antarctic oceanic system (Lancraft et al. 1989).
Surprisingly, in this study Antarctic krill Euphausia superba was usually poorly represented in the stomachs of myctophids, with a few krill juveniles recorded in some stomachs of Gymnoscopelus nicholsi collected within the shelf region of South Georgia and in the Prydz Bay region (Table 5a). Only Gymnoscopelus opisthopterus exhibited an important krill component in its gut contents. In the Lazarev Sea and in the Prydz Bay region, krill was absent from all stomachs of Electrona antarctica, even when specimens of this myctophid were collected as a by-catch in krill trawls in the Prydz Bay region (O. Gon pers. comm.). These results suggest that the role of Antarctic krill in the feeding ecology of myctophids may have been greatly overestimated in the past. Previous studies have shown that Antarctic krill comprises 50 to $90 \%$ of the total mass of the food bolus only in the stomachs of a few Antarctic species, e.g. G. nicholsi, G. opisthopterus and E. antarctica (Rowedder 1979, Kozlov \& Tarverdieva 1989, Sabourenkov 1991). We suggest that a substantial consumption of krill by myctophids occurs only during certain periods and within specific regions. This is quite obvious in the case of the most abundant myctophid, Electrona carlsbergi, for which E. superba is an important food source only during the summer season (Naumov 1985, Zasel'sljy et al. 1985, Kozlov \& Tarverdieva 1989, Oven et al. 1990). This question has important implications for Southern Ocean carbon flux and more attention is certainly required to determine the role that Antarctic krill has in the feeding budget of myctophids. 
Table 5b. Diet composition of a further 14 myctophid species collected in the Southern Ocean durng the period $1985-1995$ CW: Ceratoscopelus warmingi; SB: Symbolophorus boops; SBR: S. barnardi; HH: Hygophum hanseni; HHI: H. higomil; LAL: Lampanyctus alatus; LAU: L. australis; LP: L. pusillus; KA: Krefftichthys andersoni; LD: Lobianchia dolfeni; LP: Lampadema ponifex; DA: Dio-genichthys atlanticus; SM: Scopelopsis multipunctatus; NR: Notoscopelus resplendens

\begin{tabular}{|c|c|c|c|c|c|c|c|c|c|c|c|c|c|c|}
\hline Stomach contents & $C W$ & $\mathrm{SB}$ & SBR & $\mathrm{HH}$ & $\mathrm{HHI}$ & LAL & LAU & LP & $\mathrm{KA}$ & $\mathrm{LD}$ & LP & DA & SM & NR \\
\hline \multicolumn{15}{|l|}{ Copepoda } \\
\hline Rhincalanus gigas & - & - & - & - & - & - & - & - & 1.7 & - & - & - & - & - \\
\hline Calanus simillimus & - & - & - & - & - & - & - & - & 61.8 & - & - & - & - & 17.5 \\
\hline Calanus australis & - & - & - & - & 9.5 & - & - & - & - & - & - & - & - & - \\
\hline Calanus spp. & 1.2 & - & 33.3 & - & - & - & - & - & - & 16.7 & - & - & - & - \\
\hline Calanoides acutus & - & - & - & - & - & - & - & - & 3.6 & - & - & - & - & - \\
\hline Clausocalanus spp. & 1.5 & - & - & - & - & - & - & - & 11.2 & - & - & - & - & - \\
\hline Microcalanus spp. & - & - & - & - & 4.8 & - & - & - & - & - & - & - & - & - \\
\hline Ctenocalanus spp. & 2.4 & - & - & - & - & - & - & - & 5.7 & - & - & - & - & - \\
\hline Metridia gerlachei & - & - & - & - & - & - & - & - & 7.8 & - & - & - & - & - \\
\hline Metridia lucens & 30.1 & 82.0 & - & 3.4 & - & - & - & - & - & 8.3 & - & - & - & - \\
\hline Metridia spp. & 1.8 & - & - & - & - & - & - & - & 4.2 & - & - & - & - & - \\
\hline Pleuromamma abdominalis & - & - & - & 48.3 & - & - & - & 33.3 & - & 16.7 & -- & - & - & - \\
\hline Pleuromamma spp. & 40.4 & 1.6 & 33.3 & 44.8 & 28.6 & 46.2 & 72.7 & - & - & 50.0 & - & 10.5 & - & 25.0 \\
\hline Lucicutia spp. & - & - & - & - & - & - & - & - & - & - & 20.0 & - & - & - \\
\hline Candacia spp. & 0.6 & - & - & - & 42.9 & - & - & - & - & - & - & - & - & - \\
\hline Calanoida & 3.3 & - & - & - & - & 7.7 & 18.2 & 33.3 & - & 8.3 & - & 5.31 & 100.0 & - \\
\hline Oithona spp. & - & - & - & - & - & - & - & - & - & - & - & 26.3 & - & - \\
\hline Oncaea spp. & 2.7 & - & - & - & 9.5 & 23.1 & - & - & - & - & 60.0 & 47.4 & - & - \\
\hline Corycaeus spp. & - & - & - & - & 4.8 & - & - & - & - & - & - & - & - & - \\
\hline \multicolumn{15}{|l|}{ Ostracoda } \\
\hline Conchoecinae & 0.6 & 0.7 & - & - & - & - & - & 16.7 & - & - & - & - & - & - \\
\hline \multicolumn{15}{|l|}{ Euphausiacea } \\
\hline Euphausia similis & 2.4 & 1.3 & - & - & - & - & - & - & - & - & - & - & - & - \\
\hline Euphausia (furcilia) & 5.1 & 2.0 & - & 3.4 & - & 15.2 & - & - & - & - & 20.0 & - & - & - \\
\hline Thysanoessa gregaria & - & 0.3 & - & - & - & - & - & - & - & - & - & - & - & - \\
\hline Thysanoessa spp. & 1.8 & 0.6 & - & - & - & - & - & - & 3.6 & - & - & - & - & 12.5 \\
\hline Nematoscelis megalops & 0.3 & 0.3 & - & - & - & - & - & - & - & - & - & - & - & - \\
\hline Euphausiacea & 1.5 & - & - & - & - & - & - & - & 0.3 & - & - & - & - & 37.5 \\
\hline \multicolumn{15}{|l|}{ Decapoda } \\
\hline Zoea decapoda & - & 0.3 & - & - & - & - & - & - & - & - & - & - & - & - \\
\hline \multicolumn{15}{|l|}{ Amphipoda } \\
\hline Themisto gaudichaudi & - & 0.7 & - & - & - & 7.7 & - & - & - & - & - & - & - & - \\
\hline Phronima sedentaria & - & 1.3 & - & - & - & - & - & - & - & - & - & - & - & - \\
\hline Hyperiidea & 0.3 & 2.3 & 33.3 & - & - & - & 9.1 & - & - & - & - & - & - & - \\
\hline \multicolumn{15}{|l|}{ Polychaeta } \\
\hline Polychaeta & - & - & - & - & - & - & - & - & - & - & - & - & - & 12.5 \\
\hline \multicolumn{15}{|l|}{ Mollusca } \\
\hline Limacina spp. & 3.3 & 1.3 & - & - & - & - & - & - & - & - & - & - & - & -- \\
\hline \multicolumn{15}{|l|}{ Chaetognatha } \\
\hline Eukrohnia hamata & 0.3 & 1.3 & - & - & - & - & - & - & - & - & - & - & - & - \\
\hline Sagitta spp. & - & 0.7 & - & - & - & - & - & - & - & - & - & - & -- & - \\
\hline \multicolumn{15}{|l|}{ Tunicata } \\
\hline Oikopleura spp. & 0.3 & 0.6 & - & - & - & - & - & - & - & - & - & 10.5 & - & - \\
\hline Salpa spp. & - & 0.3 & - & - & - & - & - & - & $=$ & - & - & - & - & - \\
\hline \multicolumn{15}{|l|}{ Osteichthyes } \\
\hline Protomyctophum normani & - & 0.3 & - & - & - & - & - & - & - & - & - & - & - & - \\
\hline Myctophidae & - & 0.3 & - & - & - & - & - & - & - & - & - & - & - & - \\
\hline Fish scales & - & - & - & - & - & - & - & 16.7 & - & - & - & - & - & - \\
\hline Total food items & 332 & 305 & 3 & 29 & 21 & 13 & 11 & 6 & 358 & 12 & 5 & 19 & 2 & 8 \\
\hline No. of items per stomach & $2-63$ & $1-54$ & $1-2$ & $2-15$ & $1-9$ & $2-9$ & $2-4$ & 3 & $1-185$ & $3-6$ & $2-3$ & $2-17$ & 2 & $1-4$ \\
\hline Average ISF values $(\%)$ & 1.33 & 0.87 & 0.71 & 0.85 & 1.71 & 1.97 & 1.94 & 2.42 & 4.46 & 0.48 & 1.94 & 0.76 & 025 & 0.37 \\
\hline
\end{tabular}


Generally, the number of food items found in the stomachs of the myctophid species analysed in this study is comparable with those recorded for tropical and temperate mesopelagic fish (e.g. Kinzer \& Schulz 1985, Gorelova \& Prutko 1985) and often similar to the values found for the tropical species Diaphus taaningi (Baird et al. 1975). The number of food items in a stomach is, however, a function of fish size and food composition. Therefore, the ISF is a more objective parameter for comparisons. In this study, the values of ISF were also in good agreement with those $(<4 \%$ of dry body wt) obtained for many species of myctophids throughout the World Ocean (Baird et al. 1975, Clarke 1978, Young \& Blaber 1986, Duka 1986, Kawamura \& Fujii 1988, Sameoto 1988, 1989, Kozlov \& Tarverdieva 1989, Oven et al. 1990). Maximum values (up to $\sim 5 \%$ of dry body weight; Fig. 3) were, however, lower than those recorded in tropical-temperate (up to 10 to $17 \%$ ) and even in Antarctic (up to $26 \%$ ) species (Holton 1969, Clarke 1978, Kawamura \& Fujii 1988, Sameoto 1988, Kozlov \& Tarverdieva 1989). The highest values of ISF recorded in the literature were derived from Antarctic myctophids that had been feeding on krill (Kozlov \& Tarverdieva 1989). However, the presence in these stomachs of a limited number (2 to 4) of consistently undigested individuals of Euphausia superba leads us to the conclusion that krill might have been eaten just before the catch or, more likely, in the net after capture. Our own findings seem to support this conclusion. Thus, these maximum ISFs can be regarded as the maximum daily food intake and are most probably found only occasionally in nature.

\section{Daily rations}

Unfortunately, only 2 previous estimates of daily rations for Antarctic myctophids are available in the literature. The daily ration of $\sim 5 \%$ of dry body weight, calculated by Rowedder (1979) for Electrona antarctica, is likely to represent an overestimate. This is because of the bias associated with the extrapolation to the entire year of levels of food intake obtained during the summer and within a region of high krill biomass. Despite this, Rowedder's estimate may still be considered as the upper limits of the daily consumption during summer. The estimation of the daily ration for $E$. carlsbergi obtained using an energy budget approach (Gerasimova 1991) appears more realistic. According to this estimate, E. carlsbergi would require 3.7 to
$5.6 \%$ of its wet body weight daily, or 2.5 to $3.7 \%$ of dry body weight.

Daily rations of Diaphus taaningi in continental waters off Venezuela were $0.8 \%$ of dry body weight, assuming $-3.5 \mathrm{~h}$ of feeding (Baird et al. 1975). However, extending the feeding period to $\sim 6 \mathrm{~h}$, the daily intake could be as high as $1.35 \%$ of dry body weight (Table 6). Sameoto $(1988,1989)$ showed that for the subarctic species Bentosema glaciale (which occupies a similar habitat to the Antarctic species) the daily ration ranges from $1.7 \%$ of dry body weight in adults to $8 \%$ in juveniles. Daily consumption rates of tropical and subtropical species of myctophids from other oceanic regions are higher, ranging generally between 5 and $13 \%$ of body weight (Holton 1969, Clarke 1978, Tseitlin \& Gorelova 1978, Childress et al. 1980).

The values of daily rations obtained in this study, using 3 different approaches, seem realistic as they are in good agreement with those obtained for other Antarctic, although non-myctophid, fishes (e.g. Targett 1981, Pakhomov \& Tseitlin 1992). A theoretical maximum daily ration for Antarctic myctophids can be estimated from the highest ISF recorded in the literature, $\sim 26 \%$ of wet body weight (Kozlov \& Tarverdieva 1989). Assuming that the digestion time of Antarctic krill is as long as 2 d (Targett 1981, Pakhomov \& Tseitlin 1992, Table 2), maximum daily rations may reach $\sim 13 \%$ of wet body weight, or $\sim 8 \%$ of dry body weight.

Due to the well-known problem of net avoidance and of the shallow towing technique employed in this study, our myctophid biomass estimates are likely to be grossly underestimated. We cannot therefore address 
the question of their feeding impact on zooplankton adequately. Few estimates of myctophid predation impact are available. In the upper layer of the equatorial. Pacific, Gorelova (1984) concluded that myctophids may consume from 2 to $31 \%$ (average $-10 \%$ ) of zooplankton standing stock daily. This suggests that myctophids may be among the most important consumers of oceanic zooplankton, not only in the epi-and mesopelagic layers but also in near surface waters (Gorelova 1984). In contrast, the predation impact of the most important subarctic myctophid species, Bentosema glaciale, never exceeded $0.2 \%$ of zooplankton standing stock (Sameoto 1988, 1989).

The only estimate of zooplankton consumption by Antarctic mesopelagic fish was made by Naumov (1985). The total stock of mesopelagic fish in the Southem Ocean was estimated to be close to 275 million t and the year ration was assumed as $600 \%$ of fish body weight, equivalent to an across-the-year daily ration of $-1.64 \%$ of body weight (Naumov 1985). Thus, mesopelagic fish would consume 1085 million $t$ of meso- and macrozooplankton (excluding Euphausia superba). A.s the entire Southern Ocean occupies an area of $\sim 38.1$ million $\mathrm{km}^{2}$ (El-Sayed 1978), the average annual consumption could be equal to $\sim 28.5 \mathrm{~g}$ wet $\mathrm{wt} \mathrm{m}^{-2}$ or $\sim 6.3 \mathrm{~g}$ dry wt $\mathrm{m}^{-2}$ The mean mesozooplankton biomass measured along our transect from SANAE to Cape Town was $3 \mathrm{~g}$ dry wt $\mathrm{m}^{-2}$ (Fig. 3). Using a P/B coefficient of $\sim 5 \mathrm{yr}^{-1}$, as estimated for Antarctic copepods (Voronina 1984), the secondary production will be around $15 \mathrm{~g}$ dry wt $\mathrm{m}^{-2} \mathrm{yr}^{-1}$. Thus, Antarctic mesopelagic fish predation impact could be equivalent to $\sim 40 \%$ of the annual secondary production.

On the basis of their high biomass levels, Lancraft et al. (1989) suggested that mesopelagic fish are probably the dominant predators in the Antarctic oceanic system. The results of this study show that myctophids may be among the most important consumers of secondary standing stock and production in the Southern Ocean. A more accurate assessment of the trophic importance of myctophids in the Southern Ocean requires further detailed information on their distribution, migrations, predation impact, seasonality of feeding rates and, also, estimates of their consumption by other predators.

Acknowledgements. We are grateful to Rhodes University (Grahamstown) and to the South African Department of Environmental Affairs \& Tourism for providing funds and facilities for this study. Special thanks go to O. Gon and E. Anderson (J.L.B. Smith Institute of Ichthyology, Grahamstown) for providing material and assistance with the identification of the fish collected during the various surveys. We would also like to thank the officers and crew of the RV 'Africana' and MV SA 'Agulhas' and many colleagues from the Sea Fisheries Research Institute (Cape Town) for their invaluable assistance at sea

\section{LITERATURE CITED}

Arrhenius F. Hansson S (1994) In situ food consumption by young-of-the-year Baltic Sea herring Clupea harengus: a test of predictions from a bioenergetics model. Mar Ecol Prog Ser 110:145-149

Bakkov AD (1935) How to estimate the daily food consumption of fish under natural conditions. Trans Am Fish Soc 65: $288-289$

Bailey TG, Robison BH (1986) Food availability as a selective factor on the chemical compositions of midwater fishes in the eastern North Pacific. Mar Biol 91:131-141

Baird RC, Hopkins TL. Wilson DF (1975) Diet and feeding chronology of Diaphus taaningi (Myctophidae) in the Cariaco Trench. Copeia 2:356-365

Baker A de C, Clarke MR, Harris MJ (1973) The N.I.O. combination net (RNIT $1+8)$ and further developments of rectangular midwater trawls. J Mar Biol Ass UK 53:167-184

Barange M, Pakhomov EA, Perissinotto R, Froneman PW, Verheye HM, Tauton-Clark J, Lucas MI (in press) Pelagic community structure of the Subtropical Convergence region south of Africa and in the mid-Atlantic Ocean. Deep Sea Res II

Bekker VE (1983) Myctophids of the world ocean. Nauka Press, Moscow (in Russian)

Bekker VE (1985) Distribution of myctophid fishes and the position of the biogeographical border between the islands of Saint Paul and Kerguelen. J Ichthyol 25(2): $159-162$

Blaxter JHS (1963) The feeding of herring larvae and their ecology in relation to feeding. Calif Coop Ocean Fish Invest Rep 10:79-88

Brett JR, Groves TDD (1979) Physiological energetics. In. Hoor WS, Randall DJ, Brett JR (eds) Fish physiology, Vol 8. Academic Press, New York, p 279-352

Cameron JN, Kostoris J, Penhale PA (1973) Preliminary energy budget of the ninespine stickleback (Pungitius pungitius) in an Arctic lake. J Fish Res Bd Can 30: $1179-1189$

Childress JJ, Taylor SM, Cailliet GM, Price MH (1980) Pattern of growth, energy utilization and reproduction in some meso- and bathypelagic fishes off southern California. Mar Biol 61:27-40

Chindonova YG (1987) Quantitative information on the distribution of mesopelagic fish in the south Atlantic Ocean. In: Novikov NP, Alekseev AP (eds) Resources of the Southern Ocean and problems of their rational exploitation. YugNIRO Publishers, Kerch, p 113-114 (in Russian)

Clarke TA (1978) Diel feeding patterns of 16 species of mesopelagic fishes from Hawaiian waters. Fish Bull 76 : $495-513$

Clarke TA (1980) Diets of fourteen species of vertically migrating mesopelagic fishes in Hawaian waters. Fish Bull 78:619-640

Donnelly J, Torres JJ, Hopkins TL, Lancraft TM (1990) Proximate composition of Antarctic mesopelagic fishes. Mar Biol 106:13-23

Duka LA (1986) Feeding of Ceratoscopelus warming1 (Myctophidae) in the tropical Atlantic. J lchthyol 26(5):89-95

Eggers DM (1977) Factors in interpreting data obtained by diel sampling of fish stomachs. J Fish Res Bd Can 34: $290-294$

El-Sayed SZ (1978) Primary productivity and estimates of potential yields of the Southern Ocean. In: McWhinnie MA (ed) Polar research. Westview Press, Colorado, p 141. -160 
Fänge R, Grove D (1979) Digestion. In: Hoar WS, Randall DJ, Brett JR (eds) Fish physiology, Vol 8. Academic Press, New York, p 161-260

Filin AA, Gorchinsky KV, Kiseleva VM (1991) Biomass of myctophids in the Atlantic sector of the Southern Ocean as estimated by acoustic surveys. Selected Scientific Papers (SC-CAMLR-SSP/7). CCAMLR, Hobart, Australia, p $417-431$

Gerasimova OV (1991) Feeding and food intake of Electrona carlsbergi (Tăning, 1932) Myctophidae. Selected Scientific Papers (SC-CAMLR-SSP/7). CCAMLR, Hobart, p $411-416$

Gjøsaeter J, Kawaguchi K (1980) A review of the world resources of mesopelagic fish. FAO Fish Tech Pap 193: $1-151$

Gon O, Heemstra PC (eds) (1990) Fishes of the Southern Ocean. J.L.B. Smith Instıtute of Ichthyology Publishers, Grahamstown

Gordon JDM, Nishida S, Nemoto T (1985) The diet of mesopelagic fish from the Pacific coast of Hokkaido, Japan. J Oceanogr Soc Japan 41:89-97

Gorelova TA (1984) A quantitative assessment of consumption of zooplankton by epipelagic lanternfishes (family Myctophidae) in the equatorial Pacific Ocean. J Ichthyol 23(3):106-113

Gorelova TA. Prutko VG (1985) Feeding of Diaphus suborbitalis (Myctophidae, Pisces) in the equatorial Indian Ocean. Oceanology 25(4):523-529

Holton AA (1969) Feeding behaviour of a vertically migrating lanternfish. Pacif Sci 23:325-331

Hopkins TL, Ainley DG, Torres JJ, Lancraft TM (1993) Trophic structure in the open waters of the marginal ice zone in the Scotia-Weddell confluence region during spring (1983). Polar Biol 13:389-397

Hopkins TL, Baird RC (1977) Aspects of the feeding ecology of oceanic midwater fishes. In: Anderson NR, Zahuranec BJ (eds) Oceanic sound scattering prediction. Plenum, New York, p 325-360

Hopkins TL, Torres JJ (1989) Midwater food web in the vicinity of a marginal ice zone in the western Weddell Sea. Deep Sea Res 36:543-560

Huntley ME, Lopez MDG, Karl DM (1991) Top predators in the Southern Ocean: a major leak in the biological carbon pump. Science 253:64-66

Jobling M (1986) Mythical models of gastric emptying and implications for food consumption studies. Environ Biol Fish 16:35-50

Kawamura A, Fujii F (1988) Forage of the mesopelagic fishes, Symbolophorus californiensis (Eigenmann \& Eigenmann.) and Tarletonbeania taylori Mead caught in gill nets in the northwestern North Pacific Ocean. Bull Ocean Res Inst Univ Tokyo 26:143-159

Kinzer J, Schulz K (1985) Vertical distribution and feeding patterns of midwater fish in the central equatorial Atlantic. Mar Biol 85:313-322

Kjeldson MA, Peters DS, Thayer GW, Johnson GN (1975) The general feeding ecology of postlarval fishes in the Newport River estuary. Fish Bull 73:137-144

Kozlov AN, Shust KV, Zemsky AV (1991) Seasonal and interannual variability in the distribution of Electrona carlsbergi in the southern Polar Front area (The area to the north of South Georgia is used as an example). Selected Scientific Papers (SC-CAMLR-SSP/7). CCAMLR, Hobart, p $337-367$

Kozlov AN, Tarverdieva MN (1989) Feeding of different species of Myctophydae in different parts of the Southern Ocean. J Ichthyol 29(3):160-167
Krasnopeyor EV (1990) Gut evacuation rate in the bream, Abramis brama. J Ichthyol 29(6):85-95

Lancraft TM1, Hopkins TL, Torres JJ, Donnelly J (1991) Oceanic mucronektonic/macrozooplanktonic community structure and feeding in the ice covered Antarctic waters during the winter (AMERIEZ 1988). Polar Biol 11:157-167

Lancraft TM, Torres JJ, Hopkins TL (1989) Micronekton and macrozooplankton in the open waters near Antarctic ice edge zones (AMERJEZ 1983 and 1986). Polar Biol 9: $225-233$

Lubimova TG, Shust KV, Popkov VV (1987) Specific features in the ecology of Southern Ocean mesopelagic fish of the family Myctophidae. In: Biological resources of the Arctic and Antarctic (collected papers). Nauka Press, Moscow, p 320-337 (in Russian)

Montgomery JC, Foster BA, Cargill JM (1989) Stomach evacuation rate in the planktivorous Antarctic fish Pagothenia borchgrevinki. Polar Biol 9:405-408

Naumov AG (1985) System analysis of the structure of the Antarctic waters community. In: Vinogradov ME, Flint MV (eds) Biological basis of the commercial utilization of the open regions of the Ocean. Nauka Press, Moscow, p 57-80 (jn Russian)

Naumov AG, Svetlov MF, Kozlov AN, Pinskaya IA (1981) Some features of distribution and feeding of Electrona carlsbergi (Tanning) (Myctophidae) in the Scotia Sea. J Ichthyol 21(3):467-472

Neighbors MA, Nafpaktitis BG (1982) Lipid compositions, water contents, swimbladder morphologies and buoyancies of nineteen species of midwater fishes (18 myctophids and 1 neoscopelid). Mar Biol 66:207-215

Nobel RL (1973) Evacuation rates of young yellow perch, Perca flavescens (Mitchell). Trans Am Fish Soc 102(4):759-763

Oven LS, Konstantinova MP, Shevchenko NF (1990) Aspects of reproduction and feeding of myctophids (Myctophidae) in the southwest Atlantic. J Ichthyol 30(2):115-127

Pakhomov EA, McQuaid CD (in press) Distribution of surface zooplankton and seabirds across the Southern Ocean. Polar Biol 16

Pakhomov EA, Perissinotto R, MCQuaid CD (1994) Comparative structure of the macrozooplankton/micronekton communities of the Subtropical and Antarctic Polar fronts. Mar Ecol Prog Ser 111:155-169

Pakhomov EA. Tseitlin VB (1992) Diet of seven species of Antarctic fishes and estimation of their daily ration. J Ichthyol 32(5):31-41

Perissinotto R, McQuaid CD (1992) Land-based predator impact on vertically migrating zooplankton and micronekton advected to a Southern Ocean archipelago. Mar Ecol Prog Ser 79:243-258

Robertson AA, Alexander DGW, Miller DGM (1981) Modified collapsible opening and closing midwater trawls (RMT-8 and RMT-2). Fish Bull S Afr 14:103-113

Roe HSJ, Baker A de C, Carson RM, Wild R, Shale DM (1980) Behaviour of the Institute of Oceanographic Science's rectangular midwater trawls: theoretical aspects and experimental observations. Mar Biol 56:247-259

Rowedder U (1979) Feeding ecology of the myctophid Electrona antarctica (Günther, 1878) (Teleostei). Meeresforsch $27: 252-263$

Sabourenkov EN (1991) Mesopelagic fish of the Southern Ocean - summary results of recent Soviet studies. Selected Scientific Papers (SC-CAMLR-SSP/7). CCAMLR, Hobart, p 433-457

Sabourenkov EN (1992) Myctophids in the diet of Antarctic predators. Selected Scientific Papers (SC-CAMLR-SSP/8). CCAMLR, Hobart, p 335-368 
Sameoto DD (1988) Feeding of lantern fish Benthosema glaciale off the Nova Scotia shelf. Mar Ecol Prog Ser 44: $113-129$

Sameoto DD (1989) Fieeding ecology of the lantern fish Benthosema glaciale in a subarctic region. Polar Biol 9: $169-178$

Scotto di Carlo B. Costanzo G, Fresi E, Guglielmo L, Ianora A (1982) Feeding ecology and stranding mechanisms in two lanternfishes, Hygophum benoiti and Myctophum punctatum. Mar Ecol Prog Ser 9:13-24

Targett TE (1981) Trophic ecology and structure of coastal Antarctic fish communities. Mar Ecol Prog Ser 4:243-263

Torres JJ, Belman BW, Childress JJ (1979) Oxygen consumption rates of midwater fishes as a function of depth of occurrence. Deep Sea Res 26A:185-197

Torres JJ, Somero GN (1988) Metabolism, enzymic activities and cold adaptation in Antarctic mesopelagic fishes. Mar Biol 98:169-190

Tseitlın VB (1982) Evaluation of biomass and production of mesopelagic fish in the World Ocean. Rep Soviet Union Acad Sci 264:1018-1021 (in Russian)

Tseitlin VB (1989) Reproductive and somatic production of fishes. J Ichthyol 29(4):18-25

Tseitlin VB, Gorelova TA (1978) Study of the feeding of the lanternfish Myctophum nitidulum (Myctophidae, Pisces). Oceanology 18:488-492

Tyler AV (1970) Rates of gastric emptying in young cod. J Fish Res Bd Can 27:1177-1189

This article was submitted to the editor
Tyler HR Jr, Pearcy WG (1975) The feeding habits of three species of lanternfishes (family Myctophidae) off Oregon, USA. Mar Biol 32:7-11

Vinberg GG (1956) Rate of metabolism and food requirements of fish. White Russia University Press, M.nsk (in Russian)

Vinogradov ME, Shushkina EA (1987) Functioning of the planktonic communities in the epipelagic zone of the Ocean. Nauka Press, Moscow (in Russian)

Voronina NM (1984) Pelagic ecosystems of the Southern Ocean. Nauka Press, Moscow (in Russian)

Williams R (1985) Trophic relationships between pelagic fish and euphausiids in Antarctic waters. In: Siegfried WR, Condy PR, Laws RM (eds) Antarctic nutrient cycles and food webs. Springer-Verlag, Berlin, p 452-459

Young JW, Blaber SJM (1986) Feeding ecology of three species of midwater fishes associated with the continental slope of eastern Tasmania, Australia. Mar Biol 93: $147-156$

Zasel'sliy VS, Kudrin BD, Poletayev VA, Chechenin SC (1985) Some features of the biology of Electrona carlsbergi (Taning) (Myctophidae) in the Atlantic sector of the Antarctic. J Tchthyol 25(2):163-166

Zemsky AV (1987) Studies of the major myctophid species in the eastern Antarctic Pacific sector In: Makarov RR (ed) Biological-oceanographic investigations in the Pacific sector of the Southern Ocean. VNIRO Publishers, Moscow, p 193-201 (in Russian)

Manuscript first received: June 20,1995

Revised version accepted: November 2.1995 